\title{
THE INFLUENCE OF INTERCROP PLANTS AND THE DATE OF THEIR PLOUGHING-IN ON WEED INFESTATION OF ROOT CHICORY (Cichorium intybus L.) var. sativum (Bisch.) Janch.
}

\author{
Marzena Błażewicz-Woźniak, Mirosław Konopiński \\ Department of Cultivation and Fertilization of Horticultural Plants, University of Life Sciences in Lublin, Leszczyńskiego 58 \\ 20-068 Lublin, Poland, e-mail: marzena.wozniak@up.lublin.pl
}

Received: 5.02.2009

\section{Abstract}

The field experiment was carried out in 2006-2008 in the Felin Experimental Farm (University of Life Sciences in Lublin) on podzolic soil developed from dusty medium loam. Root chicory (Cichorium intybus L.) var. sativum (Bisch.) Janch. cv. Polanowicka was involved in the experiment. The experimental factors were 3 species of intercrop plants: common vetch ( $V i$ cia sativa), phacelia (Phacelia tanacetifolia), oat (Avena sativa) and 2 dates of ploughing-in: pre-winter and spring.

In total, 26 taxons characteristic for vegetable plantations were identified in chicory weed infestation. Monocarpic species dominated, among which Senecio vulgaris, Chenopodium album, Lamium amplexicaule, Galinsoga ciliata, and Capsella bursa-pastoris were predominant. The date of ploughing-in did not significantly affect the status and size of weed infestation of chicory plots. Short-lived species occurred after pre-winter ploughing-in, while perennial - after spring ploughing-in. The application of intercrops significantly reduced chicory weed infestation as compared to the cultivation with no intercrop. The ploughing-in of Avena sativa biomass appeared to be the most efficient. The intercrop plants reduced the occurrence of Senecio vulgaris and Capsella bursa-pastoris which were the most numerous in the treatment without intercrops. Biomass of Vicia sativa favored the growth of Chenopodium album and Lamium amplexicaule. The secondary weed infestation did not depend on agrotechnical factors applied during the experiment.

Key words: weed infestation, chicory, intercrop plants, ploughing-in, tillage

\section{INTRODUCTION}

Weeds compete with crops through negative influences on their growth and yielding. The harmfulness of weeds for horticulture can be seen in many aspects, the major ones being as follows: competition for water, light, and nutrients. It leads to a reduction in crop growth, and in consequence, to a yield decrease.
To maintain a weed population below the level causing economic losses, there is a general assumption that we need to apply plant protection against weeds (D u e r , 1996).

Tillage simplifications, namely the lack of prewinter ploughing-in, which results from a will to reduce labor and energy inputs during cultivation, most often lead to the increase of weed infestation (K ę s i k and B ł a ż e w i c z - W o źn i a k, 1994; K u ś, 1998; B oström and Fogelfors, 1999; Dzienia and Dojs s, 1999; B ł a żew i c z-W oźni a k, 2003; W e be r and Hrýn c z u k, 2005). In sustainable agriculture, weeds are seen not only as crop competitors, but also as an element that improves the diversity in an agrocenosis (Marshall et al. 2003), and even one which has a positive effect on crop growth (P r o ms a kh a et al. 2006).

Applying green manures and intercrop plants becomes more and more important when farmyard manure is less and less available. They are an excellent source of organic matter and have a positive influence on maintaining high biological activity of the soil. Modifying the soil environment, they also affect weed infestation of the crop ( $\mathrm{He} \mathrm{m} \mathrm{b} \mathrm{y} \mathrm{and} \mathrm{D} \mathrm{a} \mathrm{v} \mathrm{-}$ i es, 1994; V le e s houw ers, 1997; B or ow y and Jelonkiewicz, 1999; Gutmański et al. 1999; B ł a ż e w i c z - W o źn i a k, 2004).

The present study aimed at evaluating the influence of the application of intercrop plants and the date of their ploughing-in on the status and level of primary and secondary weed infestation on a chicory plantation.

\section{MATERIALS AND METHODS}

The field experiment was carried out in 20062008 in the Felin Experimental Farm (University of 
Life Sciences in Lublin) on podzolic soil developed from dusty medium loam. Root chicory (Cichorium intybus L.) var. sativum (Bisch.) Janch. cv. Polanowicka was involved in the experiment; it is a valuable industrial plant with a high biological value due to the inulin and intibin content in its roots. The experiment was set up by means of completely randomized blocks in 4 replications. Each experimental plot was $20 \mathrm{~m}^{2}$ in area.

The experiment included the following factors:

I. Intercrop plants: common vetch (Vicia sativa), phacelia (Phacelia tanacetifolia), oat (Avena sativa);

II. Tillage:

1) traditional with ploughing-in and a set of pre-winter tillage (25-30 $\mathrm{cm}$ deep ploughing) and spring pre-sowing tillage;

2) a set of pre-sowing tillage, intercrop plants sowing (in the middle of August), deep pre-winter ploughing-in (mixing the green matter with the soil);

3) set of pre-sowing tillage, intercrop plants sowing (in the middle of August), spring ploughing-in to 15 $\mathrm{cm}$ depth (mixing the frozen plant matter with the soil).

Mineral nutrition was applied in spring at the rates of NPK 100:100:150 kg $\times \mathrm{ha}^{-1}$. The whole rates of phosphorus, as triple superphosphate and potassium in the form of potassium chloride, were introduced into the soil prior to sowing of chicory, while nitrogen as ammonium nitrate - in two equal doses: $1 / 2$ before sowing and $1 / 2$ at top-dressing.

Every year, chicory was sown at the beginning of May (8 May) at $50 \mathrm{~cm}$ spacing between the rows. The spraying with Kerb 50WP herbicide was carried out after sowing. Plants were nursed by means of manual weeding performed twice during the vegetation period. The following fungicides were applied against fungal diseases: Bravo (10 July) and Nimrod 25 (18 July, 27 July, and 29 August). First plant emergences were recorded on: 18 May 2006, 21 May 2007, and 22 May 2008. The thinning was performed a month after the plant emergence.

Weed infestation of the field was estimated every year at two dates (primary and secondary weed infestation). The first weed infestation assessment was performed on 21 June 2006, 18 June 2007, and 11 June 2008 by means of the quantitative method in 4 replications: the so-called sample areas were selected in 4 random places of the investigated treatments using a frame of $1.0 \mathrm{~m} \times 0.5 \mathrm{~m}$ in dimension. Within them, the number of every weed species was determined and they were divided into short-lived and perennial ones. The results were expressed in the number of weeds per $1 \mathrm{~m}^{2}$.

Secondary weed infestation was determined on 20 September 2006, 18 September 2007, and 20 September 2008 by means of the gravimetric method. Be- sides counting the number of a particular weed species per square meter, their fresh weight was also evaluated (in $\mathrm{g} \times \mathrm{m}^{-2}$ ). The weed infestation assessment was made in 4 replications. The obtained results were statistically processed applying variance analysis. The significant differences were checked using Tukey's test at $\mathrm{p}=0.05$.

\section{RESULTS}

\section{Primary weed infestation}

With regard to primary weed infestation of the chicory plots in 2006-2008, a total of 26 weed species, including 19 short-lived and 7 perennial ones, were identified (Tab. 1). Both after pre-winter and spring ploughing-in, Senecio vulgaris $\left(9.46 \mathrm{no} . \times \mathrm{m}^{-2}\right)$, Chenopodium album $\left(9.17\right.$ no. $\left.\times \mathrm{m}^{-2}\right)$, Lamium amplexicaule (3.15 no. $\left.\times \mathrm{m}^{-2}\right)$, Galinsoga ciliata (2.23 no. $\left.\times \mathrm{m}^{-2}\right)$, and Capsella bursa-pastoris $\left(2.08\right.$ no. $\left.\times \mathrm{m}^{-2}\right)$ were dominant. The population of Senecio vulgaris was higher after pre-winter $\left(11.79\right.$ no. $\left.\times \mathrm{m}^{-2}\right)$ than spring ploughing-in $\left(7.13\right.$ no. $\left.\times \mathrm{m}^{-2}\right)$. The pre-winter ploughing-in reduced the number of Capsella bursa-pastoris to 0.58 per $1 \mathrm{~m}^{2}$, while up to 3.58 per $1 \mathrm{~m}^{2}$ of the species were identified after the spring ploughing-in. Galinsoga ciliata reacted similarly to the date of ploughingin, whereas Chenopodium album grew at the same rate both after the spring and pre-winter ploughing-in. The spring ploughing-in eliminated Erigeron Canadensis, Thlaspi arvense, Sonchus asper, Lamium purpureum, and Galium aparine among the short-lived weeds, and Equisetum arvense among the perennial ones, from primary weed infestation. Out of durable weed species, Taraxacum officinale $\left(2.33 \mathrm{no} . \times \mathrm{m}^{-2}\right)$ and $A r$ temisia vulgaris $\left(1.96 \mathrm{no} \times \mathrm{m}^{-2}\right)$ were the most numerous both after pre-winter and spring ploughing-in, but they grew more frequently after spring ploughing-in than pre-winter one. Sonchus arvensis, as a short-term lives weed as well as Matricaria maritima ssp. inodora and Polygonum aviculare as perennial weeds, were not recorded on the plots ploughed in before winter.

The intercrop plants reduced the occurrence of Senecio vulgaris and Capsella bursa-pastoris, which were the most numerous in the control treatment, while they favored the presence of Chenopodium album and Lamium amplexicaule that grew more often in the treatments where common vetch was the intercrop (11.42 and 5.58 no. $\times \mathrm{m}^{-2}$, respectively). Senecio vulgaris was abundant in chicory cultivated after prewinter ploughing-in with no intercrop plants (33.67 no. $\times \mathrm{m}^{-2}$ ), whereas Capsella bursa-pastoris after spring ploughing-in with no intercrops $\left(8.00\right.$ no. $\times \mathrm{m}^{-2}$, on average).

The average primary weed infestation of the chicory plantation amounted to 34.01 no. $\times \mathrm{m}^{-2}$. The 


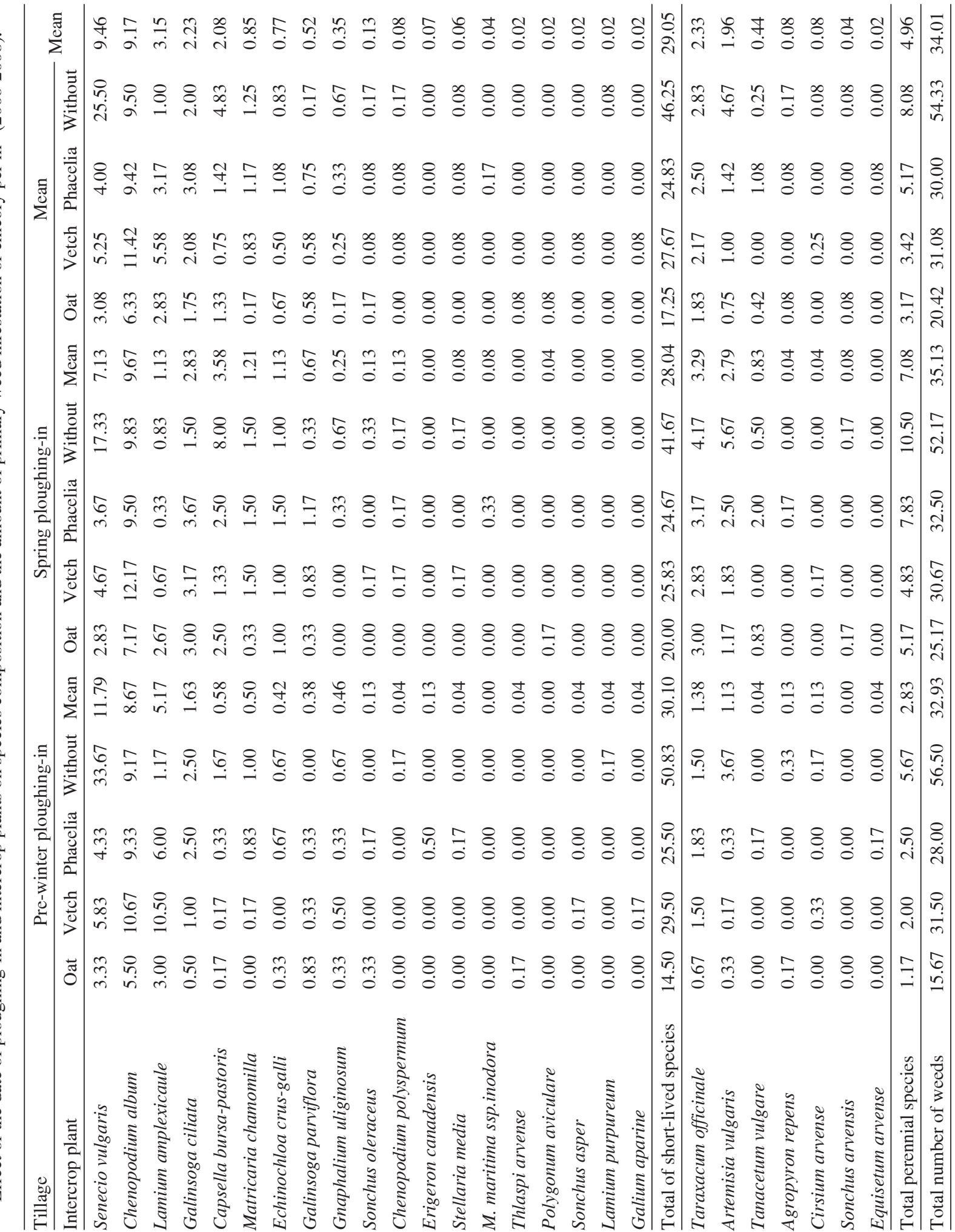




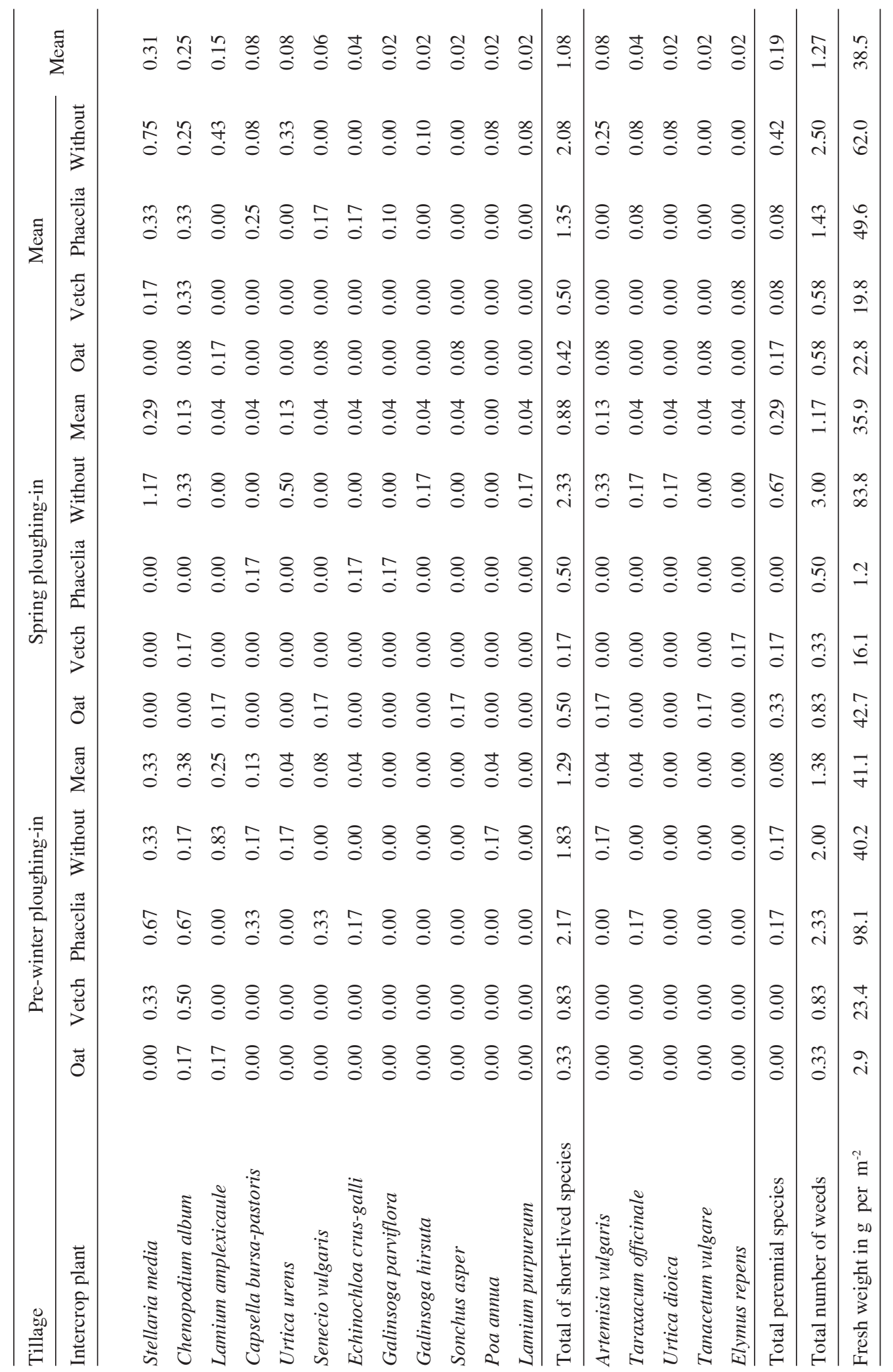



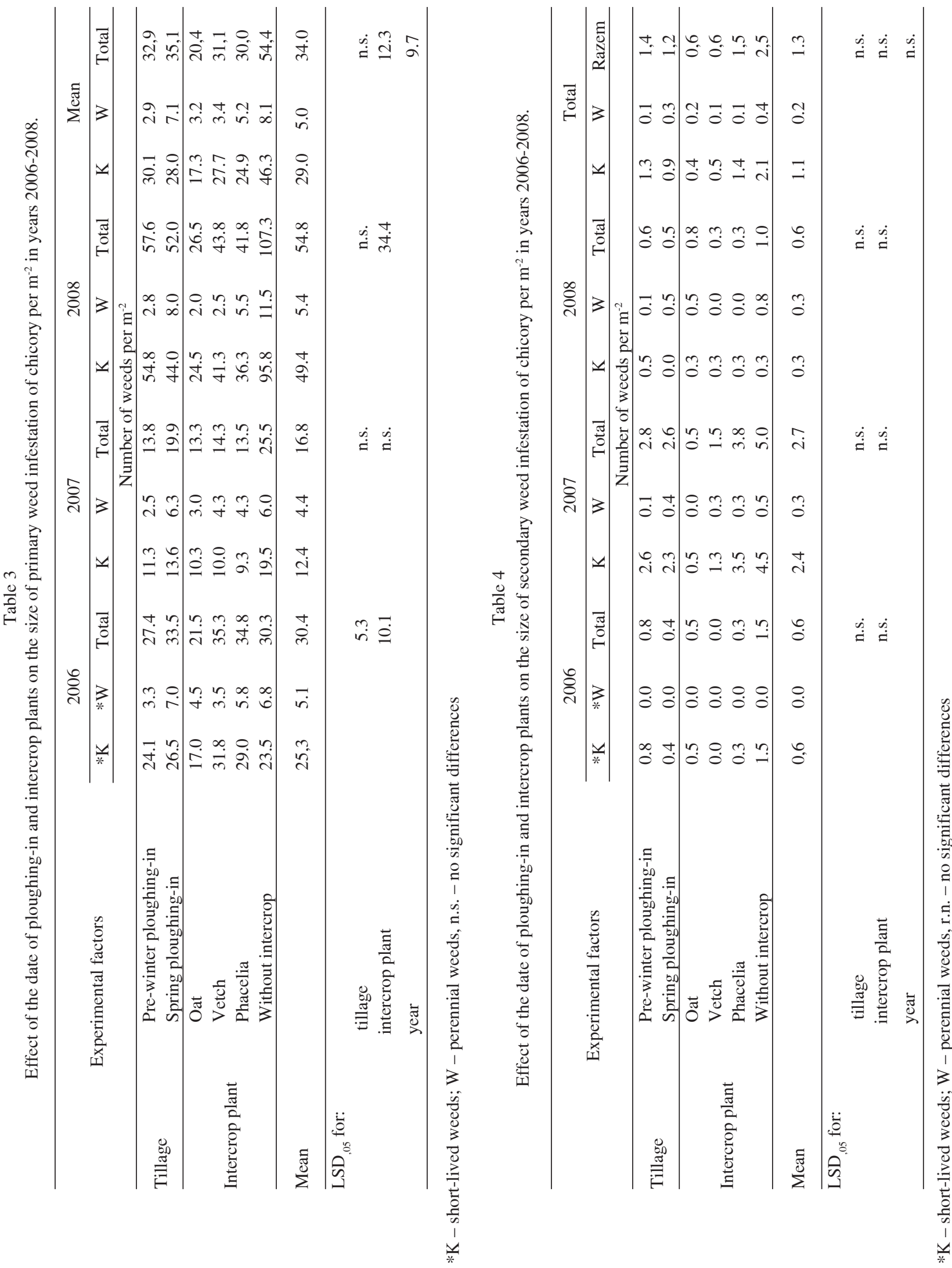
short-lived species were represented more numerously $\left(29.05\right.$ no. $\left.\times \mathrm{m}^{-2}\right)$ than the perennial ones (4.96 no. $\times$ $\left.\mathrm{m}^{-2}\right)$. The date of ploughing-in had not significant influence on the weed population (Tab. 1). The shortlived species occurred more numerously after pre-winter, while the perennial ones after spring ploughing-in (Tabs 1,2). The applied intercrop plants considerably reduced the weed population as compared to the control treatment, where weeds grew most numerously $\left(54.33\right.$ no. $\left.\times \mathrm{m}^{-2}\right)$. Such dependence was observed in all experimental years. Regardless of tillage, the smallest number of weeds was recorded in the treatments where oat mulch was mixed with the soil $\left(20.42\right.$ no. $\left.\times \mathrm{m}^{-2}\right)$. It was particularly apparent in 2008 when up to 107.3 weeds per $1 \mathrm{~m}^{2}$ were identified in the treatment with no intercrop, whilst only 26.5 after the application of oat (Tab. 2). Significant differences in chicory primary weed infestation between years were recorded. Weeds were the most abundant in $2008\left(43.3 \mathrm{no} . \times \mathrm{m}^{-2}\right)$, less in 2006 (30.4), and the least in 2007 (25.3).

\section{Secondary weed infestation}

Secondary weed infestation of the chicory plots in all experimental years was very low and amounted to 1.27 plants per $1 \mathrm{~m}^{2}$ (Tabs 3, 4). In total, 17 weed species were recorded, including 12 shortlived and 5 perennial ones. The experimental factors did not exert any influence on chicory secondary weed infestation: the plant shielding the spacing was crucial. Slightly more weeds grew in the control treatments where no intercrop plants were applied. Also, the fresh weight of weeds growing in chicory at the end of the vegetation period did not depend on the applied intercrops and the date when their biomass was mixed with the soil; it amounted to $38.5 \mathrm{~g}$ $\times \mathrm{m}^{-2}$ (mean for three years) (Tab. 3). A little more weeds per area unit were found in the treatments where no intercrop plants were grown, namely after the spring ploughing-in, which resulted from their larger population.

\section{DISCUSSION}

The chicory plantation was grown by 19 monocarpic and 7 polycarpic species within 3 experimental years. Senecio vulgaris, Chenopodium album, Lamium amplexicaule, Galinsoga ciliata, and Capsella bursapastoris among short-lives, and Taraxacum officinale among perennial species dominated, thus they were typically horticultural weeds (D o b r z a ń s k i, 1999) and belonged to the order Polygono-Chenopodietalia (R.Tx. et L o h m. 1950) J.Tx. 1961 (M a t u s zk i e w i c z , 2008). The presence of weeds typical for orchards as well as ruderal species from other syntaxons (Sisymbrietalia J.Tx. 1961 and Artemisietalia vulgaris Lohm. i R.Tx. 1947), such as Erigeron canadensis,
Artemisia vulgaris, and Tanacetum vulgare, on the chicory plantation resulted from the neighborhood of an orchard being closed down.

Usually, larger weed infestation in horticultural cultivation is recorded after spring ploughingin, which moves weed seeds up to the soil surface (Pawłowski and Wesołowski, 1981; Kęsik and B łażewicz-Woźniak, 1994). The date of ploughing-in applied in the present experiment had not any significant influence on the status and size of chicory primary weed infestation. After pre-winter ploughing-in, the short-lived species occurred, while perennial ones were present after spring ploughing-in, which resulted from the cutting of vegetative organs of polycarpic species and stimulating them to grow. Reducing the number of Equisetum arvense and the absence of Galium aparine after spring ploughing-in may be attributed to lower soil moisture content due to spring soil moisture content. It can also be supposed that the higher number of monocarpic weeds after the ploughing-in before winter resulted from the fact that pre-winter ploughing-in exerted a positive influence on soil moisture content in early spring and at the beginning of the plant vegetation period, which favored weed seed germination (K o n o p ińs ki et al. 2002), and thus a greater number of Senecio vulgaris, which prefers wet soil, grew after pre-winter ploughing-in (D o brzański, 1999). Capsella bursa-pastoris was more numerous after spring ploughing-in which brought its seeds onto the soil surface. Capsella bursa-pastoris has modest water requirements, but its seeds germinate the best from $0.5 \mathrm{~cm}$ depth (Duer, 1996). Echinochloa crus-galli and Matricaria chamomilla were also abundant after spring ploughing-in. $\mathrm{R}$ ola et al. (2005) reported an increased population of Capsella bursa-pastoris and Echinochloa crus-galli in the treatment with simplified wheat cultivation as compared to the traditional one. Chenopodium album was the species that reacted towards the date of ploughing-in the least, which was confirmed in earlier studies (Zawiej a and Kordas, 2003; C on n, 2006; Id kowiak and Kordas, 2006; S e kutowski and Rola, 2006; We s ołowski and Bujak, 2006). The method of ploughing-in, its depth, and even the shape of the mould-board, all determine the distribution of weed seeds in the soil and hence influence their germination and plant emergence (R o g e r - E s trade et al. 2001; Carter and Ivany, 2006). In the present study, pre-winter ploughing-in reduced the number of perennial weeds, namely Taraxacum officinale and Artemisia vulgaris. The effect of the date of ploughing-in on the occurrence of polycarpic weeds - among others, Elymus repens and Sonchus arvensis - was also confirmed in experiments carried out by B oström and Fogelfors (1999). 
The efficiency of intercrop plants in reducing chicory weed infestation was found in the experiment performed. The applied intercrop plants significantly decreased the occurrence of weeds as compared to the control treatment where no intercrops were used and weeds grew most abundantly. $\mathrm{Ngouajio}$ et al. (2003) observed a considerable decrease in weed infestation when cover crops were applied. It could be attributed to the allelopathic influences of compounds released during the intercrop biomass decomposition and stimulation of the activity of soil microorganisms (Dreksen et al. 1996; Kh a nh et al. 2005; P ary la k et al. 2006). The biomass of intercrop plants ploughed into the soil particularly strongly reduced the populations of Senecio vulgaris and Capsella bursa-pastoris, while Chenopodium album and Lamium amplexicaule were positively correlated to the Vicia sativa mulch. S t u p n i c k a - R o d z y n k i e w i c z et al. (2004) reported an increase of the Chenopodium album and Stellaria media populations in barley cultivated after a mixture of leguminous plants with rapeseed as the intercrop and after broad bean. $\mathrm{P}$ a w $ł$ o w s k i and W e s ołowski (1989) as well as Trąba and $\mathrm{W}$ i a t e r (2007) observed positive effects of the $\mathrm{Fa}$ baceae family plants on Chenopodium album growth. The biomass of Avena sativa reduced most strongly chicory primary weed infestation in the present experiment. After spring ploughing-in, the number of weeds in the treatment where oat mulch was applied was $48.2 \%$ relative to the control, and when fresh oat matter was ploughed in before winter - only $27.7 \%$. It should be supposed that the most favorable conditions for soil microflora development occurred in that combination. According to S t u p n i c k a - R odz y n ki e w i c z et al. (2004), the smallest number of weed species may be explained by the improvement in the air-water balance in the soil as well as by a larger population of microflora decomposing the weed seeds. The development of soil microflora is more abundant if organic remains are more vulnerable to decomposition ( $\mathrm{D}$ ą b e k - S z r e $\mathrm{n}$ i a w s k a 2004). The number and composition of soil microorganisms, along with their activity, depend on the plant species (W i e l g o s z et al. 2002). In the analyzed experiment, the oat biomass reduced the occurrence of Senecio vulgaris, Chenopodium album, Galinsoga ciliata, and Matricaria chamomilla. Lower weed infestation after the oat forecrop in spring wheat canopy was recorded by $\mathrm{W}$ e ber and $\mathrm{Hry}$ ń $\mathrm{cuk}$ (2005). P a w łow s ki and W e s ołow ski (1989) reported that Chenopodium album present in oat did not reach seed ripeness, hence it did not increase the diaspore bank in the soil.

The applied intercrop plants and the ploughingin date did not exert any influence on chicory secondary weed infestation. It resulted from the biological fea- tures of the crop whose well-developed leaves covered the soil, thus efficiently removed weeds. The number of weed species decreased by 9 in relation to primary weed infestation. The following weeds were not identified in secondary weed infestation: Matricaria chamomilla, Matricaria maritima ssp. inodora, Gnaphalium uliginosum, Thlaspi arvense, Polygonum aviculare, Erigeron canadensis, Galium aparine, and Equisetum arvense, instead Urtica urens and Poa annua appeared. Weeds grew sporadically and, in addition, they were displaced by well-developed and better-leaved chicory plants. According to J ę d r u s z c z a k et al. (2004), wintering and winter species such as Matricaria maritima ssp. inodora or Galium aparine, may be displaced by a crop when they appear with delay. Some weed species require light to emerge. The light stimulates their seeds to germinate, while the same plants emerge much worse in the dark. Such species are: Chenopodium album, Matricaria matricarioides, Polygonum aviculare, Capsella bursa-pastoris, Erodium cicutarium, Matricaria chamomilla, Matricaria maritima ssp. inodora, Senecio vulgaris, or Lamium amplexicaule, at which - after Rie mens et al. (2004) - the lack of light significantly worsened the emergence. On the other hand, the light deficiency did not have considerable effects on Urtica urens (A nders s o n et al. 1997) and Poa annua (M i l b e rg et al. 1996) emergence, which can account for their appearance in secondary weed infestation of chicory plots.

The size and status of chicory weed infestation varied in particular experimental years. Weather conditions affect the fruiting and seed shattering in weeds, as well as the course of their germination and emergence (Pawłowski and Wesołowski, 1989; Ri e mens et al. 2004; W e ber and Hryńc zuk, 2005; We s ołowski, 2006; B atlla and B enech-Arnold, 2007).

\section{CONCLUSIONS}

1. In total, 26 taxons, characteristic for vegetable plantations, were identified in chicory weed infestation, among which Senecio vulgaris, Chenopodium album, Lamium amplexicaule, Galinsoga ciliata and Capsella bursa-pastoris dominated.

2. The date of ploughing-in did not significantly affect the status and size of weed infestation of the chicory plots. Short-lived species occurred after pre-winter, while perennial ones - after spring ploughing-in.

3. The application of intercrops significantly reduced chicory weed infestation as compared to the cultivation with no intercrop. The ploughing-in of Avena sativa biomass appeared to be the most efficient.

4. The intercrop plants reduced the occurrence of Senecio vulgaris and Capsella bursa-pastoris 
which were the most numerous in the treatment without intercrops. Biomass of Vicia sativa favored the growth of Chenopodium album and Lamium amplexicaule.

5. Secondary weed infestation did not depend on agrotechnical factors applied during the experiment, whereas covering the soil by well-developed chicory leaves was crucial, since it efficiently eliminated weeds.

This study was financed by the Ministry of Science and Higher Education under PB Nr 2 P06R 01429

\section{REFERENCES}

Andersson, L., Milberg P., Noron ha A., 1997. Germination response of weed seeds to light, light of short duration and darkness after stratification in soil. Swedish J. Agric. 27: 113-120.

B atlla D., B enech-A rnold R. S., 2007. Predicting changes in dormancy level in weed seed soil banks: Implications for weed management. Crop Prot. 26: 189-197.

Błażewicz-Woźniak M., 2003. Zachwaszczenie cebuli w zredukowanym systemie uprawy roli. / Weed infestation of onion in reducing soil tillage. Acta Agrobot. 56 (1-2): 135-148.

Błażewicz-Woźniak M., 2004. Zachwaszczenie pierwotne marchwi w warunkach uprawy konserwującej. I Primary weed infestation of carrot in conservation tillage. Acta Sci. Pol., Hortorum Cultus 3 (1): 165-174.

Borowy A., Jelonkiewicz M., 1999. Zachwaszczenie oraz plonowanie ośmiu gatunków warzyw uprawianych metodą siewu bezpośredniego w mulcz żytni. / Weed infestation and yielding of eight vegetable species in no-tillage cultivation and direct sowing in rye cover crop mulches. Zesz. Probl. Post. Nauk Roln. 466, 291-300.

Boström U., Fogelfors H., 1999. Type and time of autumn tillage with and without herbicides at reduced rates in southern Sweden 2. Weed flora and diversity. Soil Till. Res. 50: 283-293.

Carter M. R., Iv a n y J. A., 2006. Weed seed bank composition under three long-term tillage regimes on a fine sandy loam in Atlantic Canada. Soil Till. Res. 90: 29-38.

Con n J. S., 2006. Weed seed bank affected by tillage intensity for barley in Alaska. Soil Till. Res. 90: 156-161.

Dobrzański A., 1999. Ochrona cebuli przed chwastami. Cebula. Technologia uprawy i przechowywania. Praca zbiorowa. IW Skierniewice.

Dreks en D. A., B la ck s aw R. E., B oyet ch o S. M., 1996. Sustainability, conservation tillage and weeds in Canada. Can. J. Plant. Sci. 76: 651-659.

Due r I., 1996. Zachwaszczenie i sposoby jego ograniczania w rolnictwie integrowanym. / Weed infestation and methods for its reduction in integrated agricluture. IUNiG Puławy.

Dzienia S., Dojss D., 1999. Wpływ sposobów uprawy roli na zachwaszczenie i plonowanie pszenicy ozimej. / Influence of systems of soil cultivation on weed infestation and yielding of winter wheat. Fol. Univ. Agric. Stetin., Agricultura, 195 (74): 185-190.

Gutmański I., Kostka-Gościniak D., SzymczakNowak J., Nowakowski M., Kłos W., Sitarski A,. 1999. Stan zachwaszczenia plantacji buraka cukrowego uprawianego z siewu w mulcz. / Weed infestation of sugar beet cultivation from direct sowing in mulch. Fol. Univ. Agric. Stetin., Agricultura, 195 (74): 105-114.

He mbry J. K., D avies J. S., 1994. Using mulches for weed control and preventing leaching of nitrogen fertilizer. Acta Hort. 371: 311-316.

Idkowiak M., Kordas L., 2006. Wpływ sposobu uprawy roli i nawożenia azotowego na zawartość diaspor w glebie. / The effect of tillage system and nitrogen fertilization on the diaspore bank in the soil. Zesz. Nauk. UP Wrocław, Rolnictwo 546: 87-93.

Jędruszczak M., Bojarczyk M., Smolarz H. J., Dąbek-Grad M., 2004. Konkurencyjne zdolności pszenicy ozimej wobec chwastów w warunkach różnych sposobów odchwaszczania - behawior zbiorowiska chwastów. / Competitive ability of winter wheat towards weeds under different weed control measures - weed community behaviour. Ann. UMCS, sect. E, 59, 2: 903-912.

Kę s i k T., B ł a że w i c z-Woźn i a k M. 1994. Wpływ uproszczeń stosowanych w przedzimowej i wiosennej uprawie roli na zachwaszczenie roślin warzywnych. / Influence of simplifications in pre-winter and spring soil tillage on weed infestation of vegetables. Ann. UMCS, sect. EEE, 2, 23: 183-194.

Khanh T. D., Chung M. I., Xuan T. D., Tawata S. 2005. The exploitation of crop allelopathy in sustainable agricultural production. J. Agronomy Crop Sci. 191 (3): 172-184.

Konopiński M., Kęs i k T., B la żewicz-Woźniak M., 2002. Agrofizyczne aspekty uproszczeń w uprawie roli. / Agrophysical aspects of simplifications in soil cultivation system. Acta Agrophysica, 60: 119-130.

K u ś J., 1998. Optymalizacja uprawy roli. IUNiG Puławy.

Marshall E. J. P., Brown V. K., B oatman N. D., Lutman P. J., Squire G. R., Ward L. K., 2003. The role of weeds in supporting biological diversity within crop fields. Weed Res. 43 (2): 77-89.

M a t u s z k i ew i c z W., 2008. Przewodnik do oznaczania zbiorowisk roślinnych Polski. / Guide for identification of plant communities of Poland. Państwowe Wydawnicto Naukowe, Warszawa.

Milberg P., Andersson L., Noronha A., 1996. Seed germination after short-duration light exposure: implications for the photo-control of weeds. J. Applied Ecol. 33: 1469-1478. 
Ngouajio M., Mc Giffen M. E. Jr., Hutchinson C. M., 2003. Effect of cover crop and management system on weed populations in lettuce. Crop Prot. 22: 57-64.

Parylak D., Zawieja J., Jędruszczak M., Stupnicka-Rodzynkiewicz E., Dąbkowska T., Snarska K., 2006. Wykorzystanie zasiewów mieszanych, właściwości odmian lub zjawiska allelopatii w ograniczaniu zachwaszczenia. / Use of the mixed crops, cultivar properties or allelopathy in weed control Prog. Plant Prot. 46 (1): 33-44.

Pawłowski F., Wesołowski M. 1981. Wpływ rodzaju i częstotliwości orek na zachwaszczenie roślin uprawnych. / The effect of type and frequency of ploughings on weed infestation of crop plants. Roczn. Nauk Roln. A, 104: 4-9.

Pawłowski F., We sołowski M., 1989. Fenologia komosy białej (Chenopodium album L.) w roślinach uprawianych na glebie bielicowej Podlasia Południowego. / The phenology of Chenopodium album $\mathrm{L}$. in plants grown on podzolic soil in Southern Podlasie. Zesz. Nauk. WSR-P w Siedlcach, Roln. 20: 205-215.

Promsakha S., Sakonnakhon Na., Cadisch G., Toomsan B., Vityakon P., Limpinuntana V., Jogloy S., Pat a nothai A., 2006. Weeds - friend or foe? The role of weed composition on stover nutrient recycling efficiency. Field Crops Res. 97: 238-247.

R ie men s M. M., S cheepen s P.C., Weide van der R. Y., 2004. Dormancy, germination and emergence of weed seeds, with emphasis on the influence of light. Plant Res. Intern. B.V., Wageningen, 302: 46 ss.

Roger-Estrade, J., Colbach, N., Leterme, P., Richard, G., Canei11, J., 2001. Modelling vertical and lateral weed seed movements during mouldboard ploughing with a skim-coulter. Soil Till. Res. 63: 35-49.

Rola H., Sekutowski T., Gierczyk T., 2005. Wpływ systemów uprawy kukurydzy w monokulturze na stan zachwaszczenia łanu. / Effect of soil tillage on weed infestation in maize monoculture. Pam. Puławski, 140: 245-249.

Sekutowski T., Rola H., 2006. Wpływ systemów uprawy na bank nasion chwastów w glebie. / Effect of tillage systems on the seed bank in soil. Prog. Plant Prot. 46 (2): 116-119.

Stupnicka-Rodzynkiewicz E., Stępnik K., Lepiarczyk A., 2004. Wpływ zmianowania, sposobu uprawy roli i herbicydów na bioróżnorodność zbiorowisk chwastów. / Effect of the crop rotation, tillage method and herbicides on the biodiversity of weed communites. Acta Sci. Pol., Agricultura, 3 (2): 235-245.

Trąb a Cz., Wi ate r J., 2007. Reakcja Chenopodium Album na rodzaj nawożenia i gatunek rośliny uprawnej. / The reaction of Chenopodium Album to the kind of manuring and crop species. Ann. UMCS, sect. E, 59 (2): 23-32.

Vlees houwers L. M., 1997. Modelling the Effect of Temperature, Soil Penetration Resistance, Burial Depth and
Seed Weight on Pre-emergence Growth of Weeds. Ann. Bot. 79: 553-563.

Weber R., Hryńczuk B., 2005. Wpływ sposobu uprawy roli i przedplonu na zachwaszczenie pszenicy ozimej. / Influence of forecrop and mode of tillage on weed infestation of winter wheat. Ann. UMCS, sect. E, 60: 93-102.

We s ołowski M., 2006. Fenologia owocowania niektórych gatunków chwastów w zasiewach wybranych roślin uprawnych. / Fruiting phenology of some weed species in sowing of chosen cultivar plants. Acta Agrobot. 59, (2): 335-344.

Wesołowski M., Bujak K. 2006. Wpływ uproszczeń w uprawie roli na zapas nasion chwastów w erodowanej glebie lessowej. / The influence of simplifications on the weed seed bank in erodible loess soil. Acta Agrobot. 59, (2): 353-363.

Wielgosz E., Szember A., Tokarzewska D., 2002. Wpływ wybranych roślin na liczebność niektórych zespołów drobnoustrojów glebowych oraz aktywność różnych grup morfologicznych bakterii amonifikujących. / The effect of selected plants on the number of some communites and activity of different morphological groups of ammonification bacteria. Ann. UMCS, sect. E, 57: 121-137.

Zawieja J., Kordas L., 2003. Effect of simplified tillage and direct sowing on weed seed bank in soil. Acta Sci. Pol. Agricultura, 2 (2): 163-170.

\section{Wpływ roślin międzyplonowych i terminu ich przyorania na zachwaszczenie cykorii korzeniowej - Cichorium intybus L. var. sativum (Bisch.) Janch.}

\section{Streszczenie}

Doświadczenie polowe przeprowadzono w latach 2006-2008 w Gospodarstwie Doświadczalnym Felin Uniwersytetu Przyrodniczego w Lublinie na glebie płowej wytworzonej z gliny średniej pylastej. Rośliną doświadczalną była cykoria korzeniowa odm. Polanowicka. W badaniach uwzględniono 3 rośliny międzyplonowe: wykę siewną (Vicia sati$v a$ ), facelię błękitną (Phacelia tanacetifolia), owies siewny (Avena sativa) oraz zróżnicowaną uprawę roli z zastosowaniem głębokiej orki przedzimowej lub płytkiej orki wiosennej.

W zachwaszczeniu cykorii oznaczono łącznie 26 taksonów w większości charakterystycznych dla upraw warzywnych. Dominowały gatunki monokarpiczne, wśród których najliczniej występowały Senecio vulgaris, Chenopodium album, Lamium amplexicaule, Galinsoga ciliata i Capsella bursa-pastoris. Termin wykonania orki nie wpłynął istotnie na stan i stopień zachwaszczenia cykorii. Po orce przedzimowej liczniej wystąiły gatunki krótkotrwałe natomiast 
po orce wiosennej - wieloletnie. Zastosowanie roślin międzyplonowych istotnie ograniczyło zachwaszczenie cykorii w porównaniu do uprawy bez międzyplonu. Najskuteczniejsze było przyoranie biomasy Avena sativa. Rośliny międzyplonowe ograniczyły występowanie Senecio vulgaris i Capsella bursa-pastoris, które najliczniej rosły w obiekcie bez międzyplonów. Biomasa Vicia sativa sprzyjała wystąpieniu Chenopodium album i Lamium amplexicaule. Zachwaszczenie wtórne nie zależało od czynników agrotechnicznych zastosowanych w doświadczeniu. 